\title{
Dimensions of Integrated Marketing Communication (IMC) and Their Impact in Creating Brand Equity in the Quick Service Restaurant (QSR) Industry in Coimbatore City
}

J Joshua Selvakumar

\section{Abstract}

Brand Equity plays a major role in the highly competitive Quick Service Restaurants (QSR) industry in India. There are a variety of factors which affect the brand equity that a company commands in the market. Integrated Marketing Communication (IMC) is an emerging concept in marketing wherein all the major promotional activities are used to create a synergic output and send across a clear and consistent message to the customers. This study aims to find out the impact of five major tools of IMC namely Advertising, Word of Mouth, Sales Promotion, Event Sponsorships and Public Relations which are most applicable in the QSR industry on the four major dimensions namely Brand Awareness, Brand Association, Perceived Quality and Brand Loyalty which aid in creating Brand Equity.

The study was conducted by collecting data from a sample and analyzing the data using statistical tools to find any relationships between the above mentioned variables. The findings suggest that marketers should focus on building favorable opinion about the brand

\footnotetext{
*Assistant Professor, PSG Institute of Management (PSG College of Technology), Peelamedu, Coimbatore, Tamil Nadu, India; joshua@psgim.ac.in
} 
amongst customers and take care regarding the news published about the brand since it affects brand image. Moreover, it was also found out that making people aware about the brand and the perceived quality about the brand play the major role in creating brand equity more than other factors.

Keywords: IMC, Brand equity, Advertising, publicity, Word of Mouth, Public relations, Brand Loyalty, Brand Association, Brand Awareness.

\section{Introduction}

\subsection{Quick Service Restaurant Industry}

A fast food restaurant, also known as a Quick Service Restaurant (QSR) within the industry itself, is a specific type of restaurant characterized both by its fast food cuisine and by minimal table service. Food served in QSRs typically caters to a "meat-sweet diet" and is offered from a limited menu; is cooked in bulk in advance and kept hot; is finished and packaged to order; and is usually available ready to take away, though seating may be provided. The Quick-Service Restaurant industry is a multi-billion dollar global industry that consists of multiple and diverse players in a market that shows no signs of tapering off. Usually success in this type of business comes from the simple model of offering remarkable customer service which is also bundled with a great tasting product.

Quick service restaurants (QSRs) are estimated to have a market of 600 million in the country. At CAGR of $25-30 \%$, QSR is the fastest growing food service segment. The industry is also witnessing entry of international chains like Dunkin' Donuts, Starbucks, etc. Currently, there are an estimated 3,000 outlets in the country. These are located in high-streets, malls, food courts in office complexes, supermarkets, and public transport stations and therefore witness a large number of footfalls.

The key players in this segment are McDonalds, Dominos, KFC, Pizza Hut, Subway, Haldiram etc. Total number of outlets is expected to reach 12,000 by 2015 . Starbucks, Quiznos and Dunkin' Donuts are also entering into the market. 


\subsection{IMC}

At the present scenario, it is essential for organizations to promote their brands well among the end-users not only to outshine competitors but also survive in the long run. Brand promotion increases awareness of products and services and eventually increases their sales, yielding high profits and revenue for the organization. To understand the concept of integrated marketing communication it is very much essential to know what brand communication is because IMC is a tool through which brand communication can be achieved. Brand communication is an initiative taken by organizations to make their products and services popular among the end-users.

\subsection{Advertising}

Advertising is non-personal communication and promotion of ideas, goods or services by an identified sponsor by various media (Kotler \& Keller, 2006, Nelson, 2010). C. Robert Clark, Ulrich Doraszelski and Michaela Draganska (2009), in their paper titled, The effect of advertising on brand awareness and perceived quality" has done an empirical investigation using panel data by combining annual brand level advertising expenditures for three hundred brands. They had measured the brand awareness and perceived quality from a large scale consumer survey and had found out their effect due to advertising. The panel data allowed them to control both heterogeneity across brand and endogeneity of advertising. From their findings they concluded that advertising has a consistent significant effect on brand awareness rather than perceived quality.

\subsection{Word of Mouth}

Word of mouth (WoM) is argued to be an informal tool of communication between private parties in which evaluation of a product or service takes place (Mazzarol et al., 2007; Lim \& Chung, 2011). A conceptual framework of hotel experience and customer based brand equity by $\mathrm{Xu}$, Jing Bill and Chan concentrates on how word of mouth contribute to customer based brand equity. This paper provides a conceptual framework for understanding hotel brand equity. They found out that hotels often use advertising, referral marketing and service marketing to help the guests understand 
brand related information. It was also found out that advertising and word of mouth can be used to generate brand awareness and brand association. Word of mouth also has an impact on the perceived quality of the brand.

\subsection{Sales Promotion}

Sales promotion is seen as temporary incentives to encourage the trial or use of a product or service (Tong \& Hawley 2009; Delvecchio et al., 2006). The effect of sales promotion on postpromotion brand preference is a meta analysis study carried on by Devon DelVecchio and David Henard. This paper tries to provide deeper knowledge on the effects of sales promotion on brand preference by combining the results from 51 studies on the subject. They found out that on an average not all sales promotion activities affect the brand preference but certain kind of promotions does have an effect to an extent. They suggest that the managers should be careful while choosing the size of the product category and should also assess the characteristics of the product before going in for sales promotion.

\subsection{Event Sponsorships}

Event sponsorship, which includes sports, music, and cultural events, has become an effective communication tool for building or enhancing brand awareness, brand image, corporate image, and directly stimulating products sales. It also can inspire customers' loyalty (Javalgi et al., 1994; Henseler et al., 2011; Tong and Hawley, 2009). Corporate sponsorship is considered an increasingly visible instrument in the marketing communication mix (Javalgi et al., 1994).

\subsection{Public Relations}

Professor Linda Aldoory in her thesis titled Public Relations and branding in health communication programs tried to understand how public relations health campaign programs can incorporate branding strategies to improve the effectiveness of the program. The author proposed a framework for integrating concepts of branding, marketing and public health campaign knowledge. The methodology used was a content analysis of internal materials and interviews with campaign managers. From the results of the study 
it was found that public relations theory, social marketing theory and branding principles have an impact on the effectiveness of the health campaigns.

\subsection{Brand Awareness}

Brand awareness is defined as "the ability of a buyer to recognize or recall that brand as a member of certain product category" (Aaker, 1991). Keller from his research found out that brand awareness composes of both brand recall and brand recognition. He also found out that brand recognition is related to consumer's ability to recall that he was previously exposed to that brand and brand recall is related to consumer's ability to retrieve the brand when given the product category as a whole.

\subsection{Brand Association}

Brand association is another important component of brand equity. It is described as "anything linked in memory to a brand" and brand image is seen as "a set of associations, usually related in some meaningful way" (Aaker, 1991). Keller (1993) defined brand associations as "impressions based on other information that is related to impressions created by the brand in the minds of consumers and that include the brand's meaning for the consumers".

\subsection{Perceived Quality}

Perceived quality is defined as "the consumer's subjective judgment about a product's overall excellence or superiority" (Zeithaml, 1988). According to Zeithaml perceived quality is not the real quality of product but the consumers' subjective assessment of that product. He has also found out from his study that personal product experience, unique needs and consumption situation can be affecting the consumer's subjective evaluation of quality.

\subsection{Brand Loyalty}

Aaker (1991) states that, brand loyalty is "a measure of the attachment that a customer has to a brand". Oliver (1979) explains brand equity as "a deeply held commitment to rebuyor re- 
patronize a preferred product or service consistently in the future, despite situational influences and marketing efforts having the potential to cause switching behavior".

\subsection{Brand Equity}

Brand equity is incremental utility and value endowed to a product or service by its brand name (Keller, 2003). This added value may be revealed in how customers consider, feel and act with the respect to a brand, as well as the prices, market share and profitability that the brand commands for the company (Kotler and Keller, 2006). Aaker (1991) proposes that, brand equity is "the set of assets (and liabilities) linked to a brand's name and symbol that adds the value provided by a product or service to a firm and /or that firm's customers." From the firm's perspectives: we can argue that a positive brand equity affects a firm's future profit and long term cash flow, the willingness of consumers to pay premium prices, long-term sustainable competitive advantage, and the marketing success of a firm (Aaker, 1991).

\section{Objectives}

1. To measure and examine the effectiveness of five selected dimensions of IMC, i.e., Advertising, Word of Mouth, Sales Promotion, Event Sponsorship and Public Relations on the dimensions of Brand Equity.

2. To measure and examine the effectiveness of Brand Equity dimensions, i.e., Brand Awareness, Brand Association, Perceived Quality and Brand Loyalty on creating Brand Equity.

3. To examine the impact of demographic factors like Age, Gender and Occupation on the various dimensions of IMC.

4. To examine the impact of demographic factors like Age, Gender and occupation on the various dimensions of Brand Equity.

5. To identify the most preferred Quick Service Restaurant (QSR) in the city of Coimbatore. 


\section{Research Methodology}

The research is focused on Quick Service Restaurants (QSR) in Coimbatore city which is accessible by the entire population. Descriptive research method was followed in this research. For the purpose of this research, the entire educated general public forms a part of the population. The method of sampling chosen for this research is convenience sampling which is a type of nonprobability sampling. Online questionnaires were sent to the target group and a total of 104 respondents answered the questionnaire. SPSS and Visual PLS were used for data analysis.

\section{Data Analysis and Interpretation}

Table 1: Reliability and AVE

\begin{tabular}{|l|c|c|c|}
\hline Construct & $\begin{array}{l}\text { Composite } \\
\text { Reliability }\end{array}$ & AVE & $\begin{array}{l}\text { Cronbach } \\
\text { Alpha }\end{array}$ \\
\hline Advertising & 0.919409 & 0.740731 & 0.883611 \\
\hline WOM & 0.870994 & 0.629509 & 0.818314 \\
\hline Sales Promotion & 0.924886 & 0.755296 & 0.893861 \\
\hline Event Sponsorship & 0.944663 & 0.810378 & 0.924663 \\
\hline Public Relations & 0.886279 & 0.665589 & 0.827453 \\
\hline Brand Awareness & 0.927751 & 0.762646 & 0.894494 \\
\hline Brand Association & 0.877219 & 0.64222 & 0.805425 \\
\hline Perceived Quality & 0.890671 & 0.672024 & 0.830717 \\
\hline Brand Loyalty & 0.847911 & 0.586055 & 0.760832 \\
\hline Brand Equity & 0.757811 & 0.519265 & 0.691883 \\
\hline
\end{tabular}

From Table 1, it can be inferred that the Cronbach Alpha and AVE scores of the various constructs are greater than 0.7 and 0.5 respectively in all the cases which shows that the reliability of the constructs is acceptable. 
Table 2: Result of estimate (Bootstrap) - Structural Model

\begin{tabular}{|c|c|c|c|c|c|}
\hline 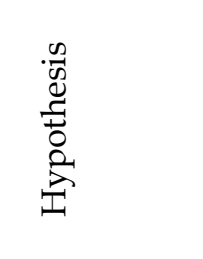 & 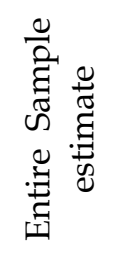 & 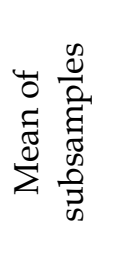 & 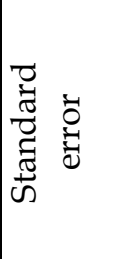 & 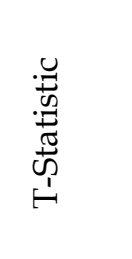 & 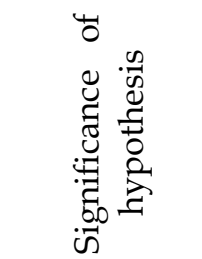 \\
\hline ADV->BA & 0.129 & 0.1603 & 0.1133 & 1.1388 & Insignificant \\
\hline ADV $->$ BAS & -0.03 & -0.1448 & 0.1141 & -0.2629 & Insignificant \\
\hline ADV->PQ & -0.239 & -0.2527 & 0.141 & -1.6944 & Insignificant \\
\hline $\mathrm{ADV}->\mathrm{BL}$ & 0.123 & 0.1571 & 0.1216 & 1.0113 & Insignificant \\
\hline WoM->BA & 0.199 & 0.1917 & 0.1223 & 1.6278 & Insignificant \\
\hline WoM->BAS & 0.303 & 0.2711 & 0.1092 & 2.7737 & Significant \\
\hline WoM->PQ & 0.263 & 0.2457 & 0.1224 & 2.1481 & Significant \\
\hline WoM->BL & 0.315 & 0.3282 & 0.1533 & 2.0543 & Significant \\
\hline $\mathrm{SP}->\mathrm{BA}$ & -0.066 & -0.1687 & 0.1203 & -0.5487 & Insignificant \\
\hline SP->BAS & -0.171 & -0.1725 & 0.1085 & -1.5754 & Insignificant \\
\hline SP->PQ & 0.111 & 0.1317 & 0.0951 & 1.1673 & Insignificant \\
\hline SP->BL & -0.012 & -0.1377 & 0.1056 & -0.1136 & Insignificant \\
\hline $\mathrm{ES}->\mathrm{BA}$ & -0.205 & -0.1831 & 0.1305 & -1.5713 & Insignificant \\
\hline ES->BAS & -0.264 & -0.2532 & 0.154 & -1.7137 & Insignificant \\
\hline$E S->P Q$ & -0.147 & -0.1753 & 0.1345 & -1.0932 & Insignificant \\
\hline $\mathrm{ES}->\mathrm{BL}$ & -0.181 & -0.1878 & 0.1254 & -1.4435 & Insignificant \\
\hline PR->BA & 0.183 & 0.2135 & 0.1313 & 1.3933 & Insignificant \\
\hline PR->BAS & 0.391 & 0.3944 & 0.1141 & 3.4265 & Significant \\
\hline PR->PQ & 0.355 & 0.3785 & 0.1256 & 2.8256 & Significant \\
\hline PR->BL & 0.159 & 0.1818 & 0.1193 & 1.3325 & Insignificant \\
\hline $\mathrm{BA}->\mathrm{BE}$ & 0.343 & 0.3955 & 0.1182 & 2.9015 & Significant \\
\hline BAS->BE & 0.022 & 0.1018 & 0.0831 & 0.2647 & Insignificant \\
\hline PQ->BE & 0.28 & 0.2666 & 0.1009 & 2.7737 & Significant \\
\hline BL->BE & 0.153 & 0.1737 & 0.0836 & 1.8295 & Insignificant \\
\hline
\end{tabular}

From table 2, it can be observed that only for values of T-statistic greater than 2, the hypotheses are considered to be significant. As such, it can be inferred that impact of Word of Mouth on Brand 
Association, Perceived Quality and Brand Loyalty is significant. Impact of Public Relations on Brand Association and Perceived Quality is significant and impact of Brand Awareness and Perceived Quality on Brand Equity is significant. The remaining are insignificant as the value is less than 2 .

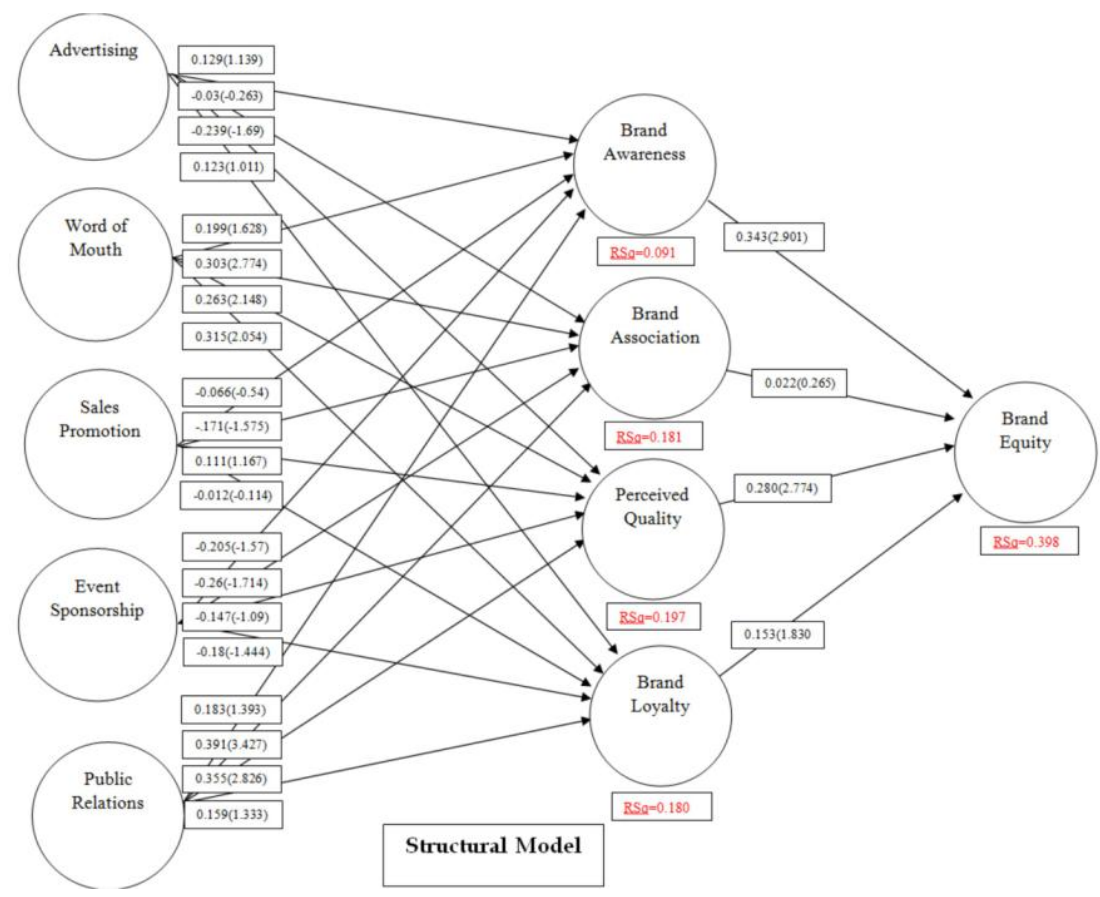

From the figure, the impact of the dimensions of IMC on the dimensions of Brand Equity can be observed with the help of R square values. The five dimensions namely Advertising, Word of Mouth, Sales Promotion, Event Sponsorships and Public Relations explain 9.1\% variation in Brand Awareness, $18.1 \%$ variation in Brand Association, $19.7 \%$ variation in Perceived Quality and 18\% variation in Brand Loyalty. The four dimensions of Brand Equity namely Brand Awareness, Brand Association, Perceived Quality and Brand Loyalty explain 39.8\% variation in Brand Equity.

The adjoining table shows the various hypotheses which are either supported or not supported by the structural model. The hypotheses supported are impact of Word of Mouth on Brand Association, Perceived Quality and Brand loyalty, impact of Public 
Relations on Brand Association and Perceived Quality and impact of Brand Awareness and Perceived Quality on Brand Equity

Table 3: Conclusion of Structural Model

\begin{tabular}{|c|c|}
\hline Hypothesis & Conclusion \\
\hline $\begin{array}{l}\text { H1a.Advertising has significant positive effect on Brand } \\
\text { Awareness. }\end{array}$ & $\begin{array}{l}\text { Not } \\
\text { Supported }\end{array}$ \\
\hline $\begin{array}{l}\text { H1b. Advertising has a significant positive effect on } \\
\text { Brand Association }\end{array}$ & $\begin{array}{l}\text { Not } \\
\text { Supported }\end{array}$ \\
\hline $\begin{array}{l}\text { H1c. Advertising has a significant positive effect on } \\
\text { Perceived Quality }\end{array}$ & $\begin{array}{l}\text { Not } \\
\text { Supported }\end{array}$ \\
\hline $\begin{array}{l}\text { H1d. Advertising has a significant positive effect on } \\
\text { Brand Loyalty }\end{array}$ & $\begin{array}{l}\text { Not } \\
\text { Supported }\end{array}$ \\
\hline $\begin{array}{l}\text { H2a. Word of Mouth has a significant positive effect on } \\
\text { Brand Awareness }\end{array}$ & $\begin{array}{l}\text { Not } \\
\text { Supported }\end{array}$ \\
\hline $\begin{array}{l}\text { H2b. Word of Mouth has a significant positive effect on } \\
\text { Brand Association }\end{array}$ & Supported \\
\hline $\begin{array}{l}\text { H2c. Word of Mouth has a significant positive effect on } \\
\text { Perceived quality }\end{array}$ & Supported \\
\hline $\begin{array}{l}\text { H2d. Word of Mouth has a significant positive effect on } \\
\text { Brand Loyalty }\end{array}$ & Supported \\
\hline $\begin{array}{l}\text { H3a. Sales Promotion has a significant positive effect on } \\
\text { Brand Awareness }\end{array}$ & $\begin{array}{l}\text { Not } \\
\text { Supported }\end{array}$ \\
\hline $\begin{array}{l}\text { H3b. Sales Promotion has a significant positive effect on } \\
\text { Brand Association }\end{array}$ & $\begin{array}{l}\text { Not } \\
\text { Supported }\end{array}$ \\
\hline $\begin{array}{l}\text { H3c. Sales Promotion has a significant positive effect on } \\
\text { Perceived quality }\end{array}$ & $\begin{array}{l}\text { Not } \\
\text { Supported }\end{array}$ \\
\hline $\begin{array}{l}\text { H3d. Sales Promotion has a significant positive effect on } \\
\text { Brand Loyalty }\end{array}$ & $\begin{array}{l}\text { Not } \\
\text { Supported }\end{array}$ \\
\hline $\begin{array}{l}\text { H4a. Event Sponsorship has a significant positive effect } \\
\text { on Brand Awareness }\end{array}$ & $\begin{array}{l}\text { Not } \\
\text { Supported }\end{array}$ \\
\hline $\begin{array}{l}\text { H4b. Event Sponsorship has a significant positive effect } \\
\text { on Brand Association }\end{array}$ & $\begin{array}{l}\text { Not } \\
\text { Supported }\end{array}$ \\
\hline $\begin{array}{l}\text { H4c. Event Sponsorship has a significant positive effect } \\
\text { on Perceived Quality }\end{array}$ & $\begin{array}{l}\text { Not } \\
\text { Supported }\end{array}$ \\
\hline $\begin{array}{l}\text { H4d. Event Sponsorship has a significant positive effect } \\
\text { on Brand Loyalty }\end{array}$ & $\begin{array}{l}\text { Not } \\
\text { Supported }\end{array}$ \\
\hline
\end{tabular}




\begin{tabular}{|l|l|}
\hline Hypothesis & Conclusion \\
\hline $\begin{array}{l}\text { H5a. Public Relations has a significant positive effect on } \\
\text { Brand Awareness }\end{array}$ & $\begin{array}{l}\text { Not } \\
\text { Supported } \\
\text { Conclusion }\end{array}$ \\
\hline $\begin{array}{l}\text { H5b. Public Relations has a significant positive effect on } \\
\text { Brand Association }\end{array}$ & Supported \\
\hline $\begin{array}{l}\text { H5c. Public Relations has a significant positive effect on } \\
\text { Perceived quality }\end{array}$ & Supported \\
\hline $\begin{array}{l}\text { H5d.Public Relations has significant positive effect on } \\
\text { Brand Loyalty }\end{array}$ & $\begin{array}{l}\text { Not } \\
\text { Supported }\end{array}$ \\
\hline $\begin{array}{l}\text { H6. Brand Awareness has a significant positive effect on } \\
\text { Brand Equity }\end{array}$ & Supported \\
\hline $\begin{array}{l}\text { H7. Brand Association has a significant positive effect on } \\
\text { Brand Equity }\end{array}$ & $\begin{array}{l}\text { Not } \\
\text { Supported }\end{array}$ \\
\hline $\begin{array}{l}\text { H8. Perceived Quality has a significant positive effect } \\
\text { Brand Equity }\end{array}$ & Supported \\
\hline $\begin{array}{l}\text { H9.Brand Loyalty has a significant positive effect on } \\
\text { Brand Equity }\end{array}$ & $\begin{array}{l}\text { Not } \\
\text { Supported }\end{array}$ \\
\hline
\end{tabular}

\section{Findings and Suggestions}

The following are the major findings from this study

1. The most preferred choice of Quick Service Restaurant was McDonalds with almost $43 \%$ respondents selecting it as their favorite.

2. Gender does not have a significant impact on any of the dimensions of IMC, Brand Equity or Brand Equity itself.

3. Occupation has a significant impact on the attitude of people towards Advertising, Event Sponsorships, Public Relations and Brand Equity.

4. All the dimensions of IMC have a significant relation with the dimensions of Brand Equity.

5. The four dimensions of Brand Equity namely Brand Awareness, Brand Association, Perceived Quality and Brand Loyalty have a significant relation with Brand Equity.

6. Word of Mouth has a significant impact on Brand Association, Perceived Quality and Brand Loyalty.

7. Public Relations has a significant impact on Brand Association and Perceived Quality. 
8. Advertising, Sales Promotion and Event Sponsorships do not have a significant impact on any of the Brand Equity dimensions.

9. Brand Awareness and Perceived Quality have a significant impact on Brand Equity.

10. Brand Association and Brand Loyalty do not have a significant impact on Brand Equity.

11. The five dimensions of IMC namely Advertising, Word of Mouth, Sales Promotion, Event Sponsorships and Public Relations account for 9.1\% variation in Brand Awareness, $18.1 \%$ variation in Brand Association, $19.7 \%$ variation in Perceived Quality and 18\% variation in Brand Loyalty. The remaining variations in these four Brand Equity dimensions may be due to many other factors which are not studied in this research.

12. The four dimensions of Brand Equity namely Brand Awareness, Brand Association, Perceived Quality and Brand Loyalty explain 39.8\% variation in Brand Equity. The remaining variation may be caused due to variety of other reasons which do not fall under the scope of this study.

From the above findings, it is obvious that Word of Mouth and Public Relations are the major building blocks in creating Brand Equity. Marketers and companies should focus more on creating favorable opinions in the minds of customers and taking care of the news that is published about the company rather than spending money, time and effort on Advertising, Sales Promotion and Event Sponsorships.

\section{Conclusion}

Brand Equity can help brand marketers and mangers to create differentiation from their competitors in order to gain competitive advantage in the market. Especially, in a highly competitive Quick Service Restaurants (QSR) industry in India, brand equity plays an essential role that affects developing business for a company. This study uses Quick Service Restaurants as an example to understand the effects of the five dimensions of IMC and four dimensions of 
brand equity in creating brand equity in the Indian Quick Service Restaurants market. From the findings of this study, it is suggested that marketers or brand managers should put their efforts on building favorable opinion in the mindset of the customers and being careful to not allow any bad publicity to tarnish the image of a brand. Under the circumstance of a highly competitive market in India, the important issue is to provide consumers with a positive or high perceived image of the brand. High perceived quality enable consumers to recognize the differentiation and superiority of a brand leading consumers to select the brand rather than other competing brands.

\section{References}

Aaker, J. L. (1997). Dimensions of brand personality. Journal of Marketing Research, 34(3), 347.

Clark, C. R., \& Doraszelski, U. (2009). The effect of advertising on brand awareness and perceived quality: An empirical investigation using panel data. Business, 207-236.

DelVecchio, D., Henard, D., \& Freling, T. (2006). The effect of sales promotion on post-promotion brand preference: A meta-analysis. Journal of Retailing, 82(3), 203-213.

Henseler, J., Wilson, B., \& Westberg, K. (2011). Managers' perceptions of the impact of sport sponsorship on brand equity: Which aspects of the sponsorship.Brand, 20(1), 7-22. Retrieved from http://researchbank.rmit.edu.au/view/rmit:12276

Kotler, P. and Keller, K.L. (2006) Marketing Management(12 ${ }^{\text {th }}$ ed). New Jersey: Pearson Prentice Hall

Lim, B, C., and Chung, M, Y. (2011). The impact of word-of-mouth communication on attribute evaluation. Journal of Business Research. 64, $18-23$.

Cui, W. (2011). Creating Consumer-Based Brand Equity In The Chinese Sports Shoes Market: Measurement, Challenges And Opportunities. Thesis. Aalborg University.

Tecau, A. S., Chitu, I. B. (1987). Changing the perception of a tourist destination through public relations, Tourism \& Hospitality Management, May 2010 Supplement, pp. 1276-1289.

Tong X., Hawley J. M. (2009), "Measuring customer-based brand equity: empirical evidence from the sportswear market in China", The Journal of Product and Brand Management, 18(4) pp. 262-71 
Zeithaml, V. A. (1998), Consumer Perceptions of Price, Quality, and Value: A Means-End Model and Synthesis of Evidence, Journal of Marketing, 52(3), 2-22. 